Revista de Biología Marina y Oceanografía

Vol. 51, №1: 171-174, abril 2016

DOI 10.4067/S0718-19572016000100016

\title{
RESEARCH Note \\ Record of a larval whalefish (family Cetomimidae) from near the Juan Fernandez seamounts, southeastern Pacific Ocean
}

Registro de una larva de pez ballena (familia Cetomimidae) de las cercanías a los montes submarinos de Juan Fernández, océano Pacífico suroriental

\section{Guillermo A. Herrera ${ }^{1}$, Mauricio F. Landaeta ${ }^{2}$ and Leonardo R. Castro ${ }^{3}$}

\author{
'Facultad de Ciencias, Universidad Católica de la Santísima Concepción, Alonso de Ribera 2850, Concepción, Chile. gherrera@ucsc.cl \\ ${ }^{2}$ Laboratorio de Ictioplancton (LABITI), Facultad de Ciencias del Mar y de Recursos Naturales, Universidad de Valparaíso, Avenida \\ Borgoño 16344, Reñaca, Viña del Mar, Chile \\ ${ }^{3}$ Laboratorio de Oceanografía Pesquera y Ecología Larval (LOPEL), COPAS-Sur Austral y Departamento de Oceanografía, Universidad \\ de Concepción, Casilla 160-C, Concepción, Chile
}

\begin{abstract}
The finding of a late flexion cetomimid specimen of $24.6 \mathrm{~mm}$ body length (BL), plus a caudal streamer of $5.7 \mathrm{~mm}$ collected in the southeastern Pacific near the Juan Fernandez seamounts $\left(33.565^{\circ} \mathrm{S} ; 77.710^{\circ} \mathrm{W}\right)$, is reported. The specimen was in good condition, almost fully pigmented, covered by small melanophores from the head to the caudal streamer, where the pigmentation is denser. It possesses an upturned mouth, developing pelvic fins with a high insertion, 14 dorsal and 15 anal fin rays, 7+7 principal caudal fin rays, ca. 54 myomeres, and a preanal distance of $75 \%$ BL. Based on the available information, the specimen can be tentatively ascribed to a species of Gyrinomimus or Cetomimus.
\end{abstract}

Key words: Cetomimidae, larva, whalefish, Juan Fernandez Seamounts

\section{INTRODUCTION}

The family Cetomimidae now comprises 20 species, in 9 genera, 6 of them monotypic. They are commonly known as whalefishes and as adults they inhabit the bathypelagic realm of all oceans. They are one of the most poorly known fish families (Paxton 1989), with some species known from only a single or a few specimens. Indeed, the whole family is known from about 600 specimen records. An unusual feature was that until recently, since the description of the family by Goode \& Bean (1895), it included only adult females with no records of larvae or males (Johnson et al. 2009).

There were early suggestions of relationships between the Cetomimidae and Megalomycteridae (Gosline 1971), and Cetomimidae and mirapinniforms (Robins 1974), although no clear evidence was provided. It was not until Miya et al. (2003) reported evidence of mirapinnid mtDNA that was almost identical to that of cetomimids, that it became evident that both groups were indeed the same. Finally, Johnson et al. (2009) established that the tapetails (Mirapinnidae) were larvae, and the bignose fishes (Megalomycteridae) were males of whalefishes of the family Cetomimidae. These findings exposed a case of unique and remarkable larval transformation and extreme sexual dimorphism.

The larvae of the whalefishes and a few postmetamorphic specimens were initially placed in a separate suborder,
Mirapinnatoidei (Bertelsen \& Marshall 1956), which comprised 5 species, in 3 genera within 2 families later combined as Mirapinnidae. Mirapinnids are collected mainly from epipelagic waters. They are small, with elongate bodies and opposed dorsal and anal fins close to the tail. They show some striking external features, such as wing-like pelvic fins with jugular insertion, which are lost in adults, and the presence of a long caudal projection, the caudal streamer (Charter \& Moser 1996). This ribbon-like structure can grow extensively and reach lengths several times, up to nine, the length of the body (Johnson et al. 2009).

After the recognition of the group as early stages of whalefishes, determining the correspondence of formerly mirapinnids (larvae), as well as megalomycterids (males) to adult Cetomimidae has become a relevant issue. In this note, the record of a larval cetomimid from the southeastern Pacific is reported. Some of the morphological features of the specimen are compared to those of other known larvae and juveniles of the family.

\section{MATERIALS AND METHODS}

The zooplankton sample was collected on October 11, 2006 (at 23:30 hours, local time) in the vicinity of Juan Fernandez 1 Seamount $\left(33.6^{\circ} \mathrm{S}, 78.5^{\circ} \mathrm{W}\right)$, at a station with a depth of $520 \mathrm{~m}$, 
in a vertical haul from $450 \mathrm{~m}$ to surface with a conical net $(60 \mathrm{~cm}$ diameter, $300 \mu \mathrm{m}$ mesh size) equipped with a General Oceanics ${ }^{\odot}$ flow meter for estimation of filtered sea water. The sample was preserved in $10 \%$ formaldehyde buffered with sodium borate. Measurements of some body parts are presented as \% Body Length (BL), measured from the tip of the snout to the tip of the notochord. The caudal streamer was measured from the end of the caudal fin rays at the level of the notochord tip. The specimen was deposited in the collections of the Museo de Zoología, Universidad de Concepción (MZUC-UCCC); the catalog number is 44216 .

\section{RESULTS AND DISCUSSION}

The specimen, collected at $33.565^{\circ} \mathrm{S}, 77.710^{\circ} \mathrm{W}$, measured $24.6 \mathrm{~mm}$ from the snout to the tip of the notochord. It is in late notochordal flexion with an oblique posterior margin of the hypural plates. The notochord extends posteriorly and reaches a size comparable to the caudal fin rays (Fig. 1). The caudal streamer is a short rudiment and seems to be complete; it measures $5.7 \mathrm{~mm}$ ( $24 \%$ of body length). The caudal streamer is connected to the caudal rays that are attached to the upper hypural plates. The specimen has slender body and a long and straight gut, with a preanal distance of $75 \% \mathrm{BL}$, a body depth of $6 \% \mathrm{BL}$ at the pectoral fin level, a head length of $13.7 \% \mathrm{BL}$, and a pelvic fin length of $4 \% \mathrm{BL}(1.0 \mathrm{~mm})$. The finfold is well developed dorsally and ventrally along the trunk and tail, except at the dorsal and anal fins. Pelvic fins have 3 rays and are inserted below and anterior to the base of the pectoral fins and high on the body, close to the level of the ventral margin of the pectoral fin base. Pectoral fin rays are not yet developed. Dorsal and anal fins are well developed with pterygiophores attached to the body.

Meristics data are as follows: 14 dorsal, 15 anal, $7+7$ principal caudal rays, 7 branchiostegal rays, and 3 pelvic fin rays. The pelvic fin seems to be developing, as all known cetomimid larvae do have pelvic fins with a high number of elements (4 to 10)[16$24=$ pectoral rays]. The heavy pigmentation does not allow the observation of myotomes, although the myomeres can be evidenced with increased back illumination. A total of 54 myomeres ( 35 preanal plus 19 caudal) can be counted.

The development of the pelvic fins in the specimen shows unusual features. They are in front of the pectoral fin, and inserted high on the side of the body, close to the level of the lower margin of the pectoral fin base. In larger individuals, the pelvic fins perhaps migrate as they are found more anteriorly, in a jugular position. Furthermore, the pelvic rays are oriented pointing upwards as they begin to develop. In 3 other species however, Cetostoma regani (ex Parataeniophorus gulosus), and the former mirapinnids Eutaeniophorus festivus, and Parataeniophorus brevis, the pelvic fins are located more ventrally at a similar length, and remain in that position in later stages (Bertelsen \& Marshall 1956, Herrera \& Lavenberg 1995), with pelvic fin rays pointing posteriorly.

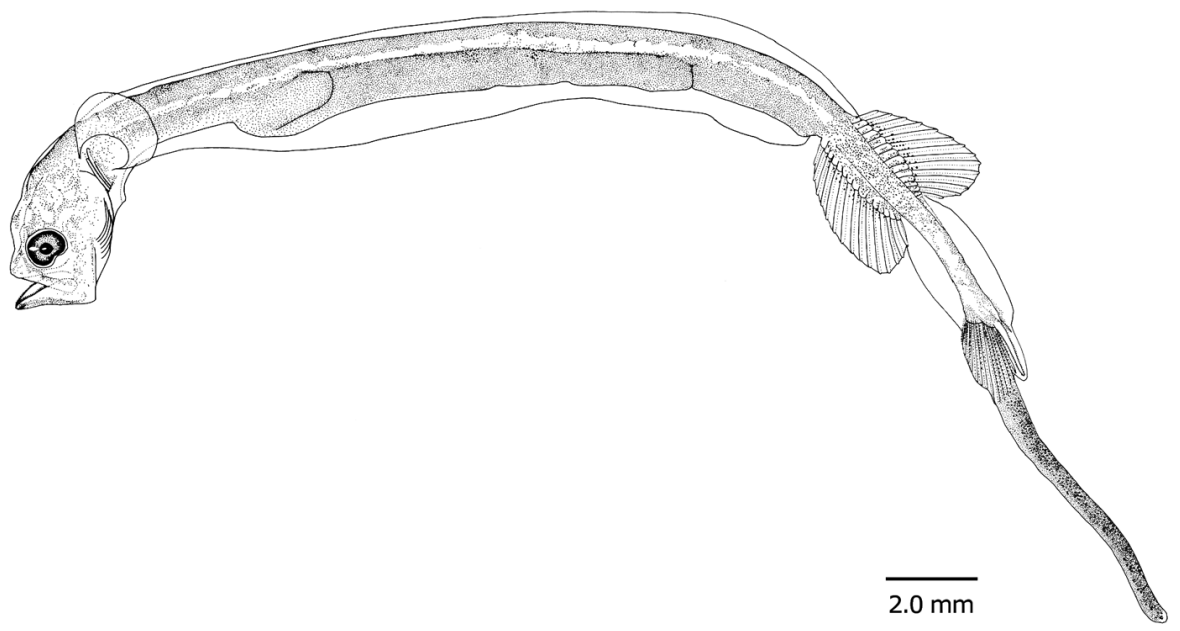

Figure 1. Cetomimid larva of $\mathbf{2 4 . 6} \mathbf{~ m m}$ notochord length, with a caudal streamer of $\mathbf{5 . 7} \mathbf{~ m m ~ ( M Z U C - U C C C ~ 4 4 2 1 6 ) ~ / ~}$ Larva de cetomímido de 24,6 mm de longitud notocordal, con un apéndice caudal de 5,7 mm (MZUC-UCCC 44216) 
Pigmentation is heavy and composed of small melanophores that pepper the entire body, the dorsal and anal pterygiophores, and the hypural plates. The caudal streamer shows an even heavier pigmentation than the body. Areas with little or no pigmentation are observed before the pectoral fins, along the side of the body from the head to the anus, and the caudal peduncle. Scattered and small melanophores are also observed near the bases of the dorsal and anal fin rays, along the margin of the tip of the notochord, between the caudal fin rays, and on the finfold near the only visible procurrent caudal ray.

From larval and juvenile cetomimids illustrated (Bertelsen \& Marshall 1958, 1984; Konishi 1988, Evseenko 1985, Shiganova 1989, Herrera \& Lavenberg 1995), all of them treated as mirapinnids, a few have been linked to adult Cetomimidae: larval 'Parataeniophorus gulosus' and males under 'Cetomimoides parri', belong to Cetostoma regani; larval 'Parataeniophorus bertelseni' to Ditropichthys storeri; and 'Mirapinna essau' to Procetichthys kreffti, by comparing DNA data or unique meristic attributes (Johnson et al. 2009).

As the bathypelagic adults and epi or mesopelagic early stages of Cetomimidae are extremely rare, the larval identification is difficult. Besides meristics and morphometrics, there seems to be some variation in certain attributes of the tapetails, which might become useful for identification. For example, differences in the development of pigmentation, in the growth of the caudal streamer, and the formation and development of pelvic fins (insertion and orientation of rays).

A specific identification of this specimen is not possible yet. Based on meristics of vertebrae, dorsal and anal fin rays, principal caudal fin rays, obtained from original descriptions and from several sources, such as Rofen (1959), Richardson \& Garrick (1964), Maul (1969), Tolley et al. (1989), but mostly from Paxton (1989: Table 10), the specimen can be tentatively linked to a species of Gyrinomimus or Cetomimus, the only two genera that might have 54 vertebrae. Two issues complicate a further specific identification. First, the limited information on distributions of species is of little help; besides, the 2 genera are the most widely spread within the family (Mincarone et al. 2014). Second, in the last comprehensive synopsis of the family, Paxton (1989) suggested that the genus Gyrinomimus might contain undescribed species. One aspect that has not received enough attention is the caudal fin structure. There seems to be variation that might be useful for identification in the future.

\section{ACKNOWLEDGMENTS}

This work was partially funded by Fondo de Investigación Pesquera (FIP) grant FIP 2006-09 adjudicated to Dr. Edwin Niklitschek. Additional funding was provided by Universidad Católica de la Santísima Concepción (Grant DIN 02/2014). We thank Eduardo Hernández for his help in the collection of the plankton samples. We also thank the reviewers for their valuable comments and advice.

\section{LITERATURE CITED}

Bertelsen E \& N Marshall. 1956. The Mirapinnati, a new order of fishes. Dana Report Carlsberg Foundation 42: 1-35.

Bertelsen E \& N Marshall. 1958. Notes on Mirapinnati. A change of name and further records (an addendum to DanaReport 42). Dana Report, Carlsberg Foundation 45: 9-10.

Bertelsen E \& N Marshall. 1984. Mirapinnatoidei: development and relationships. In: Moser HG, WJ Richards, DM Cohen, MP Fahay, AW Kendall Jr \& SL Richardson (eds). Ontogeny and systematics of fishes. American Society of Ichthyologists and Herpetologists, Special Publication 1: 380-383.

Charter SR \& HG Moser. 1996. Mirapinnidae: Ribbontails. In: Moser HG (ed). The early stages of fishes in the California Current Region. CalCOFI Atlas 33: 713-715.

Evseenko SA. 1985. Larva of a ribbontail (Eutaeniophoridae) from the Eastern Pacific Region. Journal of Ichthyology 25: $159-161$.

Goode GB \& TH Bean. 1895. On Cetomimidae and Rondeletiidae, two new families of bathyal fishes from the northwestern Atlantic. Proceedings of the United States National Museum 17: 451-454.

Gosline WA. 1971. Functional morphology and classification of teleostean fishes, 208 pp. University of Hawaii Press, Honolulu.

Herrera GA \& RJ Lavenberg. 1995. Record of a larval Parataeniophorus brevis (Pisces, Mirapinnatoidei) from Hawaii. Journal of Fish Biology 46: 908-911.

Johnson GD, JR Paxton, TT Sutton, TP Satoh, T Sado, M Nishida \& M Miya. 2009. Deep-sea mystery solved: astonishing larval transformations and extreme sexual dimorphism unite three fish families. Biological Letters 5(2): 235-239.

Konishi Y. 1988. Eutaeniophoridae. In: Okiyama M (ed). An atlas of the early stage fishes in Japan. Tokai University Press, Tokyo.

Maul GE. 1969. On the genus Cetomimus (Cetomimidae) with the description of a new species. Bocagiana 18: 1-12.

Mincarone MM, F Di Dario \& PAS Costa. 2014. Deep-sea bigscales, pricklefishes, gibberfishes and whalefishes (Teleostei: Stephanoberycoidei) off Brazil: new records, range extensions for the south-western Atlantic Ocean and remarks on the taxonomy of Poromitra. Journal of Fish Biology 85: 1546-1570. 
Miya M, H Takeshima, H Endo, NB Ishiguro, JG Inoue, T Mukai, TP Satoh, M Yamaguchi, A Kawaguchi, K Mabuchi, SM Shirai \& M Nishida. 2003. Major patterns of higher teleostean phylogenies: a new perspective based on 100 complete mitochondrial DNA sequences. Molecular and Phylogenetic Evolution 26: 121-138.

Paxton JR. 1989. Synopsis of the whalefishes (family Cetomimidae) with descriptions of four new genera. Records of the Australian Museum 41: 135-206.

Richardson LR \& JAF Garrick. 1964. A new species of Gyrinomimus (Pisces, Cetomimidae) from New Zealand. Copeia 3: 523-525.
Robins CR. 1974. Review: fishes of the western North Atlantic, part 6. Copeia 1974: 574-576.

Rofen RR. 1959. The whalefishes: families Cetomimidae, Barbourisiidae and Rondeletiidae (order Cetunculi). Galathea Reports 1:255-260.

Shiganova TA. 1989. A new species of the genus Parataeniophorus (Osteichthyes; Mirapinnatidae) from the northern-eastern part of the Atlantic Ocean. Zoologischeskii Zhurnal 68: 147-150.

Tolley SG, JV Gartner Jr \& TM Lancraft. 1989. Whalefishes (Berycyformes: Cetomimoidei) of the Gulf of Mexico. Bulletin of Marine Science 45: 671-677. 